\title{
Containing the risk of catastrophic climate change
}

\author{
Aart Reinier Gustaaf Heesterman ${ }^{1}$ (D)
}

Received: 27 November 2019 / Accepted: 27 May 2020 / Published online: 15 June 2020

(c) Springer-Verlag GmbH Germany, part of Springer Nature 2020

\begin{abstract}
There is a general perception that limiting emissions of carbon dioxide will be sufficient to avoid catastrophic climate change. The reality could well be that the many of the world's wealthy coastal cities which historically developed as ports will be inundated repeatedly to disappear eventually below the sea, with large swathes of the earth being flooded. Other major conurbations may cease to be liveable without air conditioning, while large numbers of people could well starve as a result of disruption of ecosystems. To the extent that this possibility is recognized, it is nevertheless perceived as a gradual process with the worst results in a distance future with any sea-level rise a gradual process. Limiting emissions is unlikely to be sufficient, because the level of carbon dioxide in the earth's atmosphere is now much higher than ever before since humans started to exploit fossil fuels. We know this from the study of ancient air bubbles in Antarctic ice cores. There is a lack of balance between the energy transmitted by the incoming sunlight and the earth's outgoing infrared heat radiation. So far this imbalance is absorbed by the enormous thermal mass of the oceans. As to the speed of sea-level rise, a period of extremely rapid sea-level rise of about $1.4 \mathrm{~cm}$ per year has occurred in the prehistoric past and disintegration of ice sheets as is happening currently may well be a plausible explanation of this fact. In fact, it is straightforward to create substantial amounts of negative emissions of carbon dioxide. Nevertheless, making it happen will require an unprecedented degree of global cooperation, a high level of taxation on the extraction of coal and crude oil, and the use of pressurized liquid petrol gas as aviation fuel.
\end{abstract}

\section{Graphic abstract}

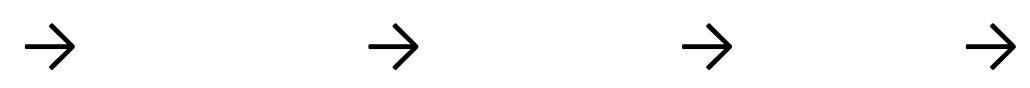

Anaerobic digestion $\mathrm{CO}_{2}$ captured and stored less $\mathrm{CO}_{2}$ in atm. risks contained

\section{$\rightarrow$ \\ Emissions continue}

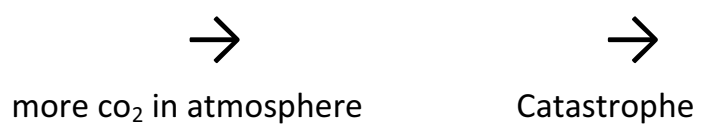

Catastrophe

\section{The cause of climate change and its enhancing feedbacks}

Milankovitch (1930) postulated that basic cause of a cycle of ice ages and warmer periods on earth was due to the intensity of the Northern hemisphere June sunshine. He listed ice

Aart Reinier Gustaaf Heesterman

ARGHees@BTInternet.com

1 University of Birmingham, Birmingham, UK cover and its reflection potential on the amount of sunshine back into space as an enhancing feedback. The reference to Northern hemisphere June sunshine is logical. Permanent ice forms much more readily on land, and the amount of land in the sub-arctic climate zone, where variations in ice cover are most likely, is much greater in the Northern than in the Southern hemisphere.

The transition from the last ice age to the Holocene interglacial period appears to have been associated with 
a rapid climate change. Thus, Blanchon and Shaw (1995) commented:

Massive inputs of ice not only produced catastrophic sea-level rise, drowning reefs and destabilizing other ice sheets, but also rapidly reduced the elevation of the Laurentide ice sheet, flipping atmospheric circulation patterns and forcing warm equatorial waters into the frigid North Atlantic. Such dramatic evidence of catastrophic climate and sea-level change during deglaciation has potentially disastrous implications for the future, especially as the stability of remaining ice sheets -such as in West Antarctica- is in question.

These authors also report that the disruption of the growth of (sunlight requiring and radiocarbon datable) coral reefs indicates that there were pulses of rapid sea-level rise. The growth of coral reefs could not keep up with the rise of the sea level, which must therefore have been more than $14 \mathrm{~mm}$ $(1.4 \mathrm{~cm})$ per year. In fact, they reckon, there was a period of about 500 years during which the average sea-level rise was about $20 \mathrm{~mm}(2 \mathrm{~cm})$ per year but were unable to date any coral formation during the period in question for the reason explained above. Blanchon and Shaw (1995) commented that they did not understand what kind of mechanism could have triggered such rapid sea-level rise, e.g. the $2 \mathrm{~cm}$ per year.

Actually, there is a perfectly plausible explanation for the facts reported by these authors. Firstly, there are systematic variations in the methane and carbon dioxide content of the earth's atmosphere (Jouzel et al. 2007). There are, in addition to the ice cover feedback as mentioned by Milankovitch himself, additional enhancing feedbacks on the basic astronomical cause of cyclical climate change, the intensity of the Northern hemisphere June sunshine. Thus once the days start to become shorter again in that climate zone, then any snow still on the ground (on land) may well last until autumn to turn into ice. However, at present, the maximum distance between the Earth and the Sun is on the fourth of July (Rao 2011). This has a major influence on the pace of glaciation.

The question arises, if $2 \mathrm{~cm}$ per year sea-level rise as reported by Blanchon and Shaw (1995) can happen on the natural earth, how much faster than $2 \mathrm{~cm}$ per year could it be, if humanity adds a massive and sudden increase in the atmosphere's carbon dioxide content of the earth's atmosphere.

If the earth hadn't been affected by the carbon emissions from human activities, the weak June sunshine should make the earth colder, and colder ocean water would allow more carbon dioxide to dissolve in sea water, causing the carbon dioxide content of the atmosphere to fall.

In fact, the atmosphere's $\mathrm{CO}_{2}$ content is now rising to levels well above what Jouzel found it to be before the industrial era: never more than about 300 parts per million (ppm), but human interference with the Earth's atmosphere turned its $\mathrm{CO}_{2}$ content (now well above $400 \mathrm{ppm}$ ) from an enhancing feedback into the dominant cause.

As to other enhancing feedback mechanisms, there is, for a start, the effect from water vapour. This is a strong greenhouse gas, thought to account for about 60 per cent of the earth's greenhouse effect (American Chemical Society 2020). In fact, the amount of additional water that can be held in the atmosphere as vapour without turning into precipitation keeps increasing for every additional degree of global warming, as may be verified by consulting the abovementioned reference to the ACS. It is also the case that the carbon dioxide content of the earth's atmosphere has, on the pre-anthropocene earth, been changing (with a response lag delay) according to the temperature: cold water more readily absorbs gases, including carbon dioxide, while its absorption in the oceans reduces the amount remaining in the atmosphere.

Another enhancing feedback mechanism is due to methane venting into the atmosphere. There are two substantial deposits of methane, which are now locked in frozen freshwater ice, which could melt and cause a significant increase in the methane content of the atmosphere, unless prompt and effective action is taken to contain emissions.

One deposit is embedded in the East Siberian shelf (=an area of what is now a shallow sea, which used to be land during the ice ages with a peat forming tundra vegetation.); Wadhams (2016, Chapter 9) has raised the alarm, explaining that the water in the Arctic Ocean consists of three layers with different salinity and therefore different weights per volume: The bottom layer is very cold and saline. This water originated from the autumn separation of sea water and (largely salt free) ice, with the remaining cold, saline water being heavier and sinking to the sea floor. Above this layer of cold and salty water, there is a layer of much warmer water of Atlantic origin, ${ }^{1}$ which in its turn is overlain by another layer of much fresher ${ }^{2}$ water (at least under permanent ice cover). Wadhams then proceeds to explain that, once the permanent ice cover has melted, the saltier and warmer water will mix with the colder fresh water above it, causing the freshwater ice inside the shelf to melt. Wadhams (2016: 178) actually goes as far as surveying and, albeit with clear reservations, defending geoengineering, i.e. artificially stopping the incoming sunlight from reaching the surface of the ice.

\footnotetext{
${ }^{1}$ Some of the water in the North Atlantic Drift/Gulfstream current is actually of tropical origin.

2 There is plenty of supply of fresh water to areas of permanent ice cover which adjoin the land: In addition to melt of the underside of the ice cover, there is river runoff.
} 
He makes it quite clear that this is a "sticking plaster" while the fundamental problem remains the unsustainable composition of the atmosphere.

The second area containing huge amounts of methane locked in ice is the continental shelf off the East coast of North America. In fact, Konschnik and Jordaan (2018) report a substantial methane leakage from this area.

Hansen et al. (2016) conclude that continued high fossil fuel use during this century could possibly result in collapse of the Gulf Stream/North Atlantic drift which now transports large amounts of water from the tropical climate zone to the coast of Western Europe. Such a collapse of the Gulf Stream would equate the climate of Southern England with that of Labrador in Northern Canada. In addition, it would in all probability cause a huge release of methane from the continental shelf on the Atlantic side of North America, where this methane is now locked in freshwater ice (methane hydrates). If not cooled from above, the ice in question would be melted by the earth's internal heat.

These authors also report that such continuation of high levels of fossil fuel use would imply several metres of sealevel rise over a period of 50-150 years. Clearly a modest reduction in the use of fossil fuels is insufficient.

Clearly the rapid sea-level rise we now experience is at variance with the Milankovitch (1930) cycle as confirmed by Berger (1980): the shortest distance between sun and earth occurring in the beginning of January (WorldAtlas 2017) rather than June, and the climate would now become colder, with sea level falling and more ice forming. Instead the earth is warming and sea level rising due to human interference.

Even when we acknowledge that relatively rapid sea-level rise is a natural response to the Milankovitch astronomical cycle, there is a clear indication that it is not a smooth process, with pulses of rapid sea-level rise, associated with ice sheet disintegration. The question arises, if $2 \mathrm{~cm}$ per year sea-level rise as reported by Blanchon and Shaw (1995) can happen on the natural earth, how much faster than $2 \mathrm{~cm}$ per year could it be, if humanity adds a massive and sudden increase in the atmosphere's carbon dioxide content of the earth's atmosphere.

According to Watts (2019), referring to United Nations Environment Programme (2019), we have 12 years to take the steps to avoid catastrophic sea-level rise.

We think that several cryosphere tipping points ${ }^{3}$ are dangerously close, but mitigating greenhouse-gas

\footnotetext{
3 In this context, a "cryogenic tipping point" is a sudden development where an ice sheet (or a large part of it) rapidly slides into the ocean, where once the ice bergs are floating, immediately display their full weight of sea water, which then spreads out over the rest of the world's oceans.
}

emissions could still slow down the inevitable accumulation of impacts and help us to adapt.

Lenton et al. (2019) provide more detail on the subject. In the same vein Steffen et al. (2018) warn of the risk that: self-reinforcing feedbacks could push the Earth System toward a planetary threshold that, if crossed, could prevent stabilization of the climate at intermediate temperature rises and cause continued warming on a "Hothouse Earth" pathway even as human emissions are reduced. Crossing the threshold would lead to a much higher global average temperature than any interglacial in the past 1.2 million years and to sea levels significantly higher than at any time in the Holocene.

In the even more distant past (more than 3 million years ago), there is thought to have been a similarly high carbon dioxide content of the earth's atmosphere, which was associated with a sea level of about 20 metres higher than currently (Royal Netherlands Institute for Sea Research 2019).

In addition to the global heating feedbacks, major methane escapes from oil and natural gas wells have been considerable Menon (2020) and contribute to even more serious climate change.

The US state of Pennsylvania was in the "heyday" of fracking the hub of it, bringing a period of enormous material prosperity with it for a while. (Eavis 2020). By December 2019, there was a surge in bankruptcies of oil and gas companies (Kimani 2020). Fracking in Pennsylvania has been at considerable cost to the earth's climate. Two reports by the Environmental Defence Fund $(2018,2020)$ document that the actual methane emissions in Pennsylvania were an order of magnitude higher than the amounts officially declared to the Environmental Protection Agency. An issue of compliance with the law arises in this context. There is in the USA a legal requirement to report emissions to the Environmental Protection Agency, and accordingly, the EPA issues instructions (Environmental Protection Agency 2018) as to precisely how this requirement should be fulfilled. Seriously under-reporting emissions would appear to be a less than bona fide compliance with the law. A system of Value Added Tax, such as in force in the European Union where the supplier to the end user, e.g. a road side fuel station, is required to pay tax upfront, but can be credited for payments made by its supplier, is more likely to restrict this kind of waste and contempt of the law: Pennsylvania has been the epicentre of fracked gas extraction in the USA since the first decade of the twenty-first century. There are also still over a hundred active oil wells. However far more wells, maybe some two hundred thousand, have been abandoned, many of them leaking methane (Associated Press 2020). 


\section{The poleward flow of water and latent heat via the atmosphere}

Because warm air containing water vapour is lighter than the much colder air in the polar climate zone, air rising in the tropical climate zone moves poleward at high levels, carrying a large amount of latent heat with it, to move back towards the tropical climate zone at lower altitude. During the Cretaceous geological period, the Arctic Ocean was, at least on its surface, sufficiently warm and salt-arm to allow crocodiles to live there, while coal was formed on Antarctica (New Scientist 2008). A reasonable explanation of this relative warmth of the polar areas is that, under impact of much more local warming in the tropical and subtropical parts of the earth than in the polar areas, the poleward flow of air and the transport of latent heat contained in the water vapour in it went into overdrive. The notion that the anthropocene phase of global warming is likely to be as drastic as happened in the Cretaceous may be far-fetched, but avoiding less extreme climate change is an urgent priority.

Rapid sea-level rise is also enhanced, because meltwater can seep from the surface of an ice sheet through crevasses to frozen clay at its bottom, causing this to soften and become slippery thereby allowing part of the sheet to slide into the ocean. Ice on land above sea level does not displace any ocean water, while floating ice does, thereby causing the sea level to rise. Once that happens, the resulting icebergs can travel thousands of kilometres and melt over a large area of ocean. For example, some 9000 pieces of rock, thought to originate from Antarctica, were found at Cape of Good Hope, off the coast of South Africa (Needham 1962). This author comments, correctly in my opinion, that the only way this material could have come there is by being rafted with floating ice.

\section{Climate change is happening now}

The earth is heating up now, and I hereby mention some recent examples that show that weather events have become more extreme, resulting in prolonged periods of torrential rain and/or punishing drought giving rise to devastating fires.

At least 60 people died when heavy rain and catastrophic flooding hit the Indonesian capital Jakarta in the beginning of 2020. (Bloomberg 2020)

The Indonesian city of Jakarta flooded again Friday night, with many parts of the city still under water on Saturday. The same thing happened last week. The same thing happened last month too, leaving dozens dead and illustrating yet again why the government plans to move its capital in the coming years. (Fagan 2020).
Other regions also had to struggle with unprecedented amounts of precipitation, such as Egypt: "On Thursday, 12 March 2020, stormy weather and heavy rainfall caused major flooding in Egypt, killing at least 20 people." (Egyptian Streets 2020). Note that normally Egypt has (had) a desert climate with an average annual rainfall of $24.7 \mathrm{~mm}$. per year (Wikipedia 2020a). Even on Greenland, an island normally covered in dry snow, because of the

Rain is becoming more frequent in Greenland and accelerating the melting of its ice, a new study has found. (Stukman 2019)

In addition it was much warmer than regarded normal for the regions in question,

Last summer was so warm it helped trigger the loss of 600 billion tonnes of ice from Greenland-enough to raise global sea levels by $2.2 \mathrm{~mm}$ in just 2 months, research has found ${ }^{4}$ (Milman 2020).

This piece of information appears to be based on an oral communication with Isabella Velicogna, Professor of Earth Sciences at the University of California, Irvine, whose laboratory specializes in the relation between ice and the sea.

It wasn't only much warmer in the North, Antarctic ice sheets are beginning to drift away, thereby allowing glacier fronts to slide into the Arctic Ocean which has been warming as well, even to the extent that king crabs are moving up the slope of the Antarctic floor (McClintock 2012, Chapter 6).

At tidal frequencies, the grounding line extends over a several kilometre-wide grounding zone, enabling warm ocean water to melt ice at critical locations for glacier stability. If warm, modified Circumpolar Deep Water reaches the sub-ice-shelf cavity and continues to melt ice at a rate exceeding balance conditions, the potential exists for Denman Glacier to retreat irreversibly into the deepest, marine-based basin in Antarctica. (Brancato et al. 2020)

The focus with respect to ice melt and the implied sealevel rise has until recently been on West Antarctica: It was thought that the East Antarctica ice sheet was unlikely to slide into the ocean because there was no obvious route over the bedrock between ice sheet and the Southern Ocean, However, these authors identified a gap in this undersea protection of the East Antarctica ice sheet, thereby raising the question whether the East Antarctic ice sheet really is as

\footnotetext{
${ }^{4}$ This is not necessary the same as ice melt. When a part of an ice sheet slides into the sea, it immediately displaces the full weight of the ice, with most of the resulting ice bergs being under water, replacing sea water.
} 
stable as it has so far been thought to be. They report a several kilometres deep sea area below the Denman glacier, which presumably now has a relatively low salt content, but any contact between the ocean and this large body of water under the ice would clearly enhance its salt content.

We have an extra month of summer now. And winters are not like what they used to be. That's why we can make wine, and why 50 years ago, we couldn't. (Henley 2020)

The country, where it is now feasible to grow wine grapes, was Sweden, which surely nobody would associate with viticulture.

Australia: Nation endures hottest day on record (BBC News 2019a, 18 Dec).

Extreme heat frequently leads to devastating fires, which earlier ravaged parts of Portugal and the USA, and more recently Australia, where people had to fly for their lives, at times jumping into the sea.

Thousands of people have fled to a beach in Victoria, Australia, to escape bushfires racing towards the coast. (BBC News 2019b, 31 Dec)

\section{How to contain at least the worst forms of climate change}

\section{Carbon capture from the combustion of biomethane}

Capture and storage of carbon dioxide from the flue gases of power stations fuelled with biomethane, combined with oxygen from another source than ambient air, is known as oxyfuel combustion. This technology could create a significant amount of negative emissions. Note also that the methane content of biogas obtained from substances containing proteins such as sewage or food waste can be significantly enhanced by adding carbon dioxide and employing appropriate bacteria (Fernández et al. 2014).

Raw biogas contains a considerable percentage of carbon dioxide as well as water vapour. It often also contains a smaller amount of sulphur in the form of $\mathrm{H}_{2} \mathrm{~S}$ (hydrogen sulphide) (The Biogas, undated). However, there are means of removing these contaminants, or indeed pre-empting them to arise in the first place. (Ryckebosch et al. 2011). I gather from the description of the process of transforming raw biogas into biomethane by these authors, that it consists of three successive phases, viz: (1) removing or alternatively pre-empting the generation of $\mathrm{H}_{2} \mathrm{~S}$, (2) removing other trace components, and (3) separating the methane from the carbon dioxide. Concerning (1) I reckon adding iron into the digester is the preferable method: Both iron and sulphur are essential constituent parts of proteins. Therefore, adding iron into the mixture inside an anaerobic digester means that the soils from which the digested material came and to which the digestate is returned, is enriched with iron, presumably in the form of $\mathrm{FeS}_{2}$ (pyrite) rather than depleted of sulphur. As to (2), ammonia is no problem: It is listed as a trace component, and is very well soluble in water (The Engineering Toolbox, undated). There won't be any significant amount of it left once the biogas has been depleted of water vapour by compression and cooling. The other contaminants that can occur in biogas include siloxanes (compounds containing oxygen as well as silicon). They would, if present in the gas input stream of a power station be harmful because they would cause silicon to be deposited inside the combustion chamber. However if the methane is to be used as fuel for a methane burning power station, it is, as far as the other "contaminants", which include heavier hydrocarbon compounds, sufficient to remove the water vapour from essentially sulphur-free biogas by getting it to condense by compression and cooling, and the ammonia will be dissolved in the condensing water. I suggest that there is no real need for any other use of methane gas, apart from its role as fuel for oxyfuel combusting electric power stations: Its use in industry and domestic heating and cooking could be replaced by electricity. The resulting essentially sulphur-free carbon dioxide and methane mixture from anaerobic digesters could then be transported via the existing gas grid to power stations burning methane in oxyfuel combustion. Removal of siloxanes can then be dealt with at the power station. There will be a need to build pipelines to transport carbon dioxide from power stations burning biomethane to suitable endstorage sites, but no significant other investment needs arise, other than the basic investment in installations to harvest renewable energy such as wind turbines and solar panels. I am assuming that a significant part of additional electricity generation will be in the form of local roof mounted solar panels, backed up by in situ battery storage. In that case no additional strain on the local grid arises.

To avoid internal damage to the power station, the oxygen to carbon dioxide content of the "substitute air" (= oxygen and carbon dioxide) should approximate consist of 1 part oxygen to 4 parts carbon dioxide, to match the $20 \%$ oxygen and $80 \%$ nitrogen in air.

It is desirable to get at a situation where the flue gas output stream consists of carbon dioxide and water vapour only, as one would expect in oxyfuel combustion of methane. That makes it easy to get pure carbon dioxide by the simple process of cooling and compressing, thereby causing the water vapour to condense to liquid water.

The way to get to a situation where the flue gas output stream consists of carbon dioxide and water vapour only is as follows: Firstly, the flue gas stream needs to be cooled. This is readily achieved by of a counterflow system of vertical 
coils. The one containing the flue gas stream and the water condensing out of it should have the hot flue gas stream entering at the top, with carbon dioxide, some remaining water vapour and liquid water emerging at the bottom. The other coil should have cold water come in at the bottom, and heated water at the top. If a mixture of the two emerging water flows has the appropriate temperature, it could be used in combined heat and power, for direct use as hot water, and/ or for use in indoor water filled heating radiators.

If substitute air of the above-mentioned composition used in combustion of methane is to result in all the methane being burnt with no unused oxygen left, a requirement on the composition of the total gas input stream to the power station arises.

To establish what this requirement is, we need to know how much oxygen is needed to combust all the methane in the total gas input stream, without any oxygen being left.

The equation which states the combustion of pure methane is:

$\mathrm{CH}_{4}+2 \mathrm{O}_{2} \rightarrow \mathrm{CO}_{2}+2 \mathrm{H}_{2} \mathrm{O}$

The 2 to 1 oxygen to methane ratio and the $20-80$ ratio of substitute air therefore means that required composition of the input stream is:

10 parts methane, 20 parts oxygen and 80 parts carbon dioxide, adding up to 110 parts in total.

That is an eight to one carbon dioxide to methane ratio. Such a ratio is very much higher than the one which is typical for biogas. In other words, although some of the carbon dioxide comes from the biogas, the greater part of the $\mathrm{CO}_{2}$ in the input stream needs to come from recycling carbon dioxide from the flue gas stream into the input stream. This can be done, by adding an amount of oxygen to the biogas equal to twice its methane content, and an amount of cooled carbon dioxide that brings its carbon dioxide content up to 8 times its methane content. To avoid a too high temperature, as well as an undesirable high water vapour content of the total gas input stream, the flue gas stream therefore needs to be cooled. That can be done by means of a counterflow system of vertical coils. The one containing the flue gas stream and the water condensing out of it should have the hot flue gas stream coming in at the top, with carbon dioxide, some remaining water vapour and liquid water coming out at the bottom. The other coil should have cold water come in at the bottom, and heated water at the top. If a mixture of the two outcoming water flows has the appropriate temperature, it could be used in combined heat and power, for direct use as hot water, and/ or for use in indoor water filled heating radiators. Use of that mixture would, however, require investment, not just at the power station, but in well-insulated hot water pipes, to bring the hot water to where hot water is needed. Otherwise, the heat exchange system would just serve to get a carbon dioxide and water vapour mixture that is suitable to be added to the purpose of meeting the required composition as stated above without the input stream becoming undesirable hot or containing a large amount of water vapour.

At this point we note two things: The amount of carbon embedded in the remaining carbon dioxide content of the flue gas stream is logically equivalent to the amount of carbon embedded in the methane and carbon dioxide content of the gas input stream, including the recycled carbon dioxide. It follows that avoidance of undesirable venting of $\mathrm{CO}_{2}$ into the atmosphere requires that all of its content in the flue gas stream should either be permanently stored, or else processed into carbon containing substances. The other point to be noted at this point is that conversion of an electricity generating power station as it used to be does not require anything else than instrumentation and hardware that regulates recycling of part of the flue gas stream. Conversion of a methane burning power station to an oxyfuel combusting one is achieved, by instrumentation and hardware that ensures that 80 out of 110 parts of the gas input stream are not combustible, even if initially containing nitrogen. It is then sufficient to either (temporarily) dispose of carbon dioxide and nitrogen mixture or separate the two components by cryogenic distillation. That will ensure that the composition of the flue gas stream will in any case converge to carbon dioxide and steam only.

\section{Production of synthetic fuels}

Oxyfuel combustion of methane and capture of the carbon dioxide content of the flue gas stream via oxyfuel combustion are an efficient way of harvesting pure carbon dioxide.

The use of electric power to convert carbon dioxide and hydrogen into sustainable synthetic fuels is uncomplicated and the only practical way to keep trans-ocean aviation going on a sustainable basis (Heesterman 2019). It is argued that rapid implementation of the available renewables technology is an urgent priority. It needs stressing too that there can be substantial delays between emissions and their impact on the climate. Nevertheless, the elevated level of the carbon dioxide content of the atmosphere associated with a prolonged period of unsustainable levels of emissions could well lead to catastrophic consequences. The energy cost and by implication a major part of the financial cost of making the technology outlined above a realistic prospect in a market economy are reviewed further down in this article, in the section "Taxation matching the energy need of synthetic fuels". 


\section{The need to harvest sustainable energy for all energy use}

As explained in the previous section, the technology to contain emissions exists, but whether it will be implemented at a speed consistent with the Paris agreement on containing climate change, that is the next question. Moreover, given the existing unsustainable level of carbon dioxide in the atmosphere, the Paris commitments may not be sufficient to avoid catastrophic climate change. Emissions need to be cut to zero as soon as possible.

The 2019 United Nations report "Peace dignity and equality on a healthy planet", referring to a more technical 2018 IPCC special report, reported that limiting global warming to $1.5^{\circ} \mathrm{C}$ would require rapid, far-reaching and unprecedented changes in all aspects of society.

This article focuses on the technological and economic side of this question. The target of restricting global warming by the end of the century to "only" 1.5 degrees above pre-industrial levels will in all probability require abandoning existing fossil fuel using equipment even while still being in good working order.

Even without the issue of still outstanding amortization of obsolete equipment complete decarbonisation will be a financial challenge due to the requirement to transform electric power.

\section{The three technological routes of carbon capture}

The three main technological routes that can be used to supply renewable energy in a form usable as supply to homes, factories, shops, transport and other business uses are summarized as follows:

(1) Generating electricity on a sustainable basis and directly using the electricity in electromotors or electric heating equipment.

(2) Producing methane gas generated by bacteria converting biogenic material into methane in anaerobic digesters (Heesterman 2020). Note that, as explained in the sub-section "Carbon capture from the combustion of biomethane" above, use of biomethane as fuel for electric power station is quite simple. It is sufficient to pre-empt the generation of hydrogen sulphide by adding iron into the digester, and not only the carbon embedded in the methane content of the raw biogas is eliminated from the atmosphere, but also the carbon dioxide content of the biogas.

(3) Using (1) to convert carbon dioxide and hydrogen generated by electrolysis of water into carbon containing fuels that can be much more easily transported and stored than is the case for electricity. The co-generation of oxygen as well as hydrogen by electrolysis of water has the additional advantage that (1) can be applied with oxyfuel combustion, i.e. the gas intake is, apart from contaminants (of which sulphur, oxidised to $\mathrm{SO}_{2}$ which is eliminated with steam condensing to water), makes it possible to have a flue gas stream consisting essentially of steam and carbon dioxide only.

It is the case that (2) is limited by the supply of non-edible biogenic material and the need for transport. However, when organic waste material is included in a regular rubbish collection, additional costs are likely be minimal. In addition there is a substantial cost difference between (1) and (3), and route (1) will be used wherever practical. The direct use of (1) is not necessarily realistic over longer periods of time and ranging over wider geographical areas, in particular when aviation is involved. This means that making route (3) at least as commercially affordably as the use of fossil fuels. This requires a high level of taxation on mining of the fuels in question. Taxation of crude oil and coal extraction/mining also bypasses the complication that shipping and aviation fuels are currently exempt from having to pay duties according to international treaties. To make such a taxation regime, a reality will require global cooperation.

\section{The drawbacks of the direct use of hydrogen as a fuel}

It is possible to use hydrogen directly as a fuel. However, hydrogen is a gas and is, due to its low critical temperature, much more difficult to transport and store than fuels in a liquid or solid state. In addition, there is a scientific opinion which questions its environmentally beneficial characteristics.

A widespread switch to burning hydrogen to heat UK homes has been suggested to meet the country's new climate targets - but a leaked report has warned the government that such a move risks inadvertently releasing harmful nitrogen oxide (NOx) pollution in densely populated towns and cities. (Vaughan 2020)

While hydrogen may have its problems, I have published some information on the renewables technology (Heesterman 2018, 2019), which underpins the statement that the use and transport of sustainable synthetic fuels is quite feasible, while the obvious example where direct use of electric power is not practical is trans-ocean aviation. I therefore suggest that we should establish a fiscal regime that ensures that taxation on the extraction of all fossil fuels from the earth is at a level at which the financial cost of aviation kerosene 
and motor fuel of fossil origin is higher than that of its sustainable equivalent. To be effective on a global scale, such a fiscal regime will need to be laid down in an international treaty. Even if this were not adopted universally, a coalition of countries in favour might need to impose duties on their imports according to their carbon contents, included their embedded carbon component. Once such a regime is in place, the direct use of electric power harvested on a sustainable basis will become the normal form of energy use for most other purposes. Note, however, that as explained in the next section on taxation, any such tax should be applicable on the carbon content of fuels of fossil origin, not on their synthetic equivalents.

As mentioned earlier in this article, there are limits laid down in international law, which give aviation and maritime transport a privileged position. I do feel that the fact that it is appropriate that the European Commission is in effect considering to abolish these benefits (Project Cargo Journal 2019).

Long-distance transport and storage of renewable energy is technologically straightforward. This is, however, not happening at a speed implying compliance with the Paris agreement on limiting emissions, let alone avoiding catastrophic climate change. Increasing amounts of carbon dioxide are still being expelled straight into the atmosphere.

\section{Taxation matching the energy need of synthetic fuels}

The energy expenditure of the use of (renewable) electric power to produce and use synthetic fuels is about thrice that of the direct use of electricity in circumstance where that is practical. This implies a global taxation regime which includes a tax on the mining of fossil fuels of at least 200 per cent of the actual extraction cost. It is useful to comment at this point that there are two criteria for determining the cost of a particular product. Pigou (1932, Ch. IX, § 10) lists a number of examples where a product or its manufacturing process causes costs or loss of amenity to others than the manufacturer: soot expelled by a chimney and the need to pay police and prison staff to contain the behaviour of drunkards. He accordingly argues that the relevant industry should be charged accordingly "with the extra costs [...] which it indirectly makes necessary". This argument is equally applicable to the damage caused by climate change. However, the cost of preventing further aggravation of climate change is likely to be very much less than that of large swathes of land and cities disappearing under the sea. Note in this context, that the real is cost of this taxation is the need to abandon and write off obsolete equipment running on fossil fuels rather than doubled the former rate. The basis of the calculation of this factor 3 as described in an earlier paper (Heesterman 2019) is summarized here as follows: As far as the direct use of electricity in power generation is concerned, it is roughly competitive with the use of fossil fuels (Supekar and Skerlos 2015). Running an internal combustion engine on synthetic fuel made from hydrogen made by electrolysis of water and carbon dioxide obtained from the flue gas stream of power station burning biomethane involves the energy expenditure of the electrolysis of water. This is comparable to that of the production of the oxygen needed to burn the methane in oxyfuel combustion. That means that the use of electricity in electrolysis of water would be a straight conversion of one form of energy, electricity, into another form of motor fuel, if the conversion of carbon dioxide and hydrogen into motor fuel were 100 per cent efficient. In fact the conversion via the Fischer-Tropsch process has an efficiency of only about $60 \%$. In addition we need to take account of the fact that the efficiency of the internal combustion engine is only about half that of the electromotor. Therefore the conclusion has to be that running an internal combustion engine on synthetic fuel made by electrolysis of water and the FT process requires about 3 times the amount of electric energy than the direct use of the same amount of electricity in an electromotor. Given that both internal combustion engines and jet engines depend on the expansion of hot gases rather than magnetism, we may reasonably assume that this calculation generalizes to aviation fuel as well. For details see Heesterman (2019) and references provided there.

For most uses of energy on the ground, the direct use of electricity is almost certainly less expensive than three times its primary generation cost, even when the expense of longdistance transport via high-voltage direct current cables and storage in batteries are included. The cost argument would be even more compelling if the long-term result of a fiscal regime as proposed would be that (sustainable) electricity became the dominant form of power supply. However, this is impractical in the case of transatlantic flight because it would require a very heavy battery. Aircraft as now in use require a fuel that is liquid both at -50 degrees Centigrade at near stratospheric height, and at plus 30 degrees Centigrade in the heat of a tropical day. I reckon planes could fly on synthetic LPG (= Liquid Petroleum Gas, normally propane, but butane will do as well) stored in liquid form in pressurized tanks synthetic LPG, see: Heesterman 2018, 2019).

To ensure that (renewable) synthetic fuels are always cheaper than their fossil equivalents for all uses of energy, the tax should be applicable to the extraction of fossil fuels rather than on specific applications, such as motor fuel. And it should relate to their carbon content. That would also ensure that the proposed tax does not inhibit the production of their synthetic equivalents: Manufacture (and presumably use) of synthetic fuels from carbon dioxide and hydrogen 
does not cause additional emissions of carbon dioxide. One complication that could arise from such a drastic increase in the cost of liquid motor fuel is the danger that it could, either via blending, or even on its own, make common alcohol (ethanol) an even more cost effective motor fuel than it already is. It is widely used as such and defended as a sustainable alternative to the use of liquid motor fuel. (Sugarcane 2020)

Sugarcane ethanol is an alcohol-based fuel produced by the fermentation of sugarcane juice and molasses. Because it is a clean, affordable and low-carbon biofuel, sugarcane ethanol has emerged as a leading renewable fuel for the transportation sector.

Any defence of ethanol overlooks the fact that the planting of sugar cane for this purpose is already a major cause of environmental destruction, in particular in Brazil. The same issue also arises in relation to palm oil as diesel fuel. Hooijer et al. (2006) documented its role as major driver of emissions in S.E. Asia.

In Brazil, sugar cane is primarily grown in the Cerrado savannah region of the southeast, where only $40 \%$ of the native ecosystem remains. (Yale School of Forestry \& Environmental Studies 2020)

Clearly, without restrictions on blending automotive fuel with "sustainable" biofuels a further major stimulus to environmental destruction is implied.

It would require a significant measure of global cooperation, even if not totally complete, to conclude a global taxation regime applicable on a global scale on the extraction of crude oil as well as the required administrative restrictions on the use of scarce environmental resources. A "coalition of the willing" of states serious about complying with the Paris agreement on containing climate change could decide on an appropriate tax rate, and preferably as soon as technically possible. It could then charge import duties on the estimated amount of emissions embedded in products based on fossil fuels which at present are exempt or subject to minimal taxation. If, as I would recommend, an adequate level of taxation on the primary extraction of cola and crude oil were the norm worldwide and manufacture of sustainable synthetic fuel, including aviation fuel, becomes commercially viable, then no further taxation on carbon containing end products would be required. See also Heesterman and Heesterman (2013: 190 ff). In relation to the issues of the speed at which the fossil fuel extraction tax should be introduced (Ibid: 180), it should preferably not be too fast, but a minimum of temporization remains a condition for, let us hope, getting any such scheme accepted in the real world and avoiding too serious a disruption in the normal order of the global economy. Nevertheless as an economist, I stand by my opinion that taxation is the most suitable route towards making an efficient use of the earth's scarce resources, both in terms of creating incentives to make use of the available sustainable technology. This includes the manufacture of synthetic fuels and restriction of the final demand for products that make heavy demands on so far unpriced or undercosted capabilities of the earth. I must, however, repeat and emphasize, that any such treaty would have to include provisions on restricting or taxation of other unsustainable substances, such "natural" alcohol made from sugarcane. As for compensation (Ibid: 180-181), prime candidates would appear to be pension funds and possibly banks and similar financial institutions which might otherwise be unable to meet their (re) payment commitments, as well as existing users of fossil using installations in need of incentives to switch to sustainable alternatives, but unable to do so immediately. It should not be provided to holiday makers or wealthy owners of private jets, who should instead immediately be persuaded not to fly.

While the development of renewables on current policy is clearly insufficient to avoid a climate crisis, the main reason that emissions are still increasing despite the overwhelming evidence for the need to reduce them is not technological but societal. Energy use and in particular aviation is out of control and still rising at an accelerating rate.

As it stands now, aviation is still ruining the earth climate. Or at least it was, prior to the Covid 19 outbreak.

Rosen (2017) projected the future of aviation as follows:

The growth will generate countless new routes and require hundreds of new airports and thousands of new planes and pilots. Such a dramatic increase in flight would also be accompanied by a surge in greenhouse gases linked to climate change, so the industry is doubling down on efforts to improve fuel efficiency and curb emissions.

However, any such improvement in fuel efficiency, even if it may to some extent be forthcoming, is unlikely to seriously contain emissions. As per October 22, 2019, regular aviation fuel was, at least in the UK, tax free, while automotive fuel (but not crude oil) is taxed:

At present, although road fuel is charged excise duty, which represents a substantial proportion of the pump price paid by motorists, aviation kerosene (AVTUR) which is used in jet engines is exempt from tax. (Steely 2020).

As the above quote makes clear, aviation is so far running on a business as usual fiscal regime, which includes its exemption from fuel duty. Unless something stringent measures are taken to curtail them, we can expect the projection of Graver et al. (2018) that emissions from aviation will triple by 2050 to become a reality. 


\section{The comparison between CCS and synthetic fuels}

As far as the technological side of this issue is concerned, there is an obvious requirement to invest in a number of suitable types of equipment: high-voltage direct current cable connections for long-distance transport of electric power as well as batteries. There is also an alternative method of transporting and storing energy: transport by rail of synthetic fuels produced from carbon dioxide and hydrogen created by the electrolysis of water. For a survey of this technology, see Heesterman $(2018,2019)$. In any case, the cost of energy, when and where it is needed in any form other than electricity, is significantly higher than that of the cost of harvesting it on its own. Once again, this is not a technical question. As far as the environmental side is concerned, any environmental (and safety) issue associated with renewable energy is trivial in comparison with that of climate change, but not to be dismissed. One might think of Flixboroughtype gas explosions. Although the hydrocarbon compound in question (Cyclohexane), which was involved in that particular disaster, is mainly used for the manufacture of plastics; similar mis-management of a facility to "crack" a tar-type residual of oil refining into liquid fuels to be used as motor fuel could well have a similar result.

It is also true that electric motors require (relatively scarce) raw materials in amounts which fossil fuel burning engines do not require. It is, however, a well-established fact that, once a particular substance is perceived as becoming very scarce, more deposits will be found, while the technology of extracting it in more difficult areas goes into fast mode. Remember the "oil crisis" of the early 1970s?

There is no basic technological obstacle against planes flying on synthetic fuels made from carbon dioxide and hydrogen. While this still implies emissions, these would cancel against the carbon dioxide extracted from the air or otherwise captured to the purpose of manufacturing synthetic fuels. To make this a reality under market economy conditions will require, as mentioned above, substantial taxation on the extraction of fossil fuels, possibly in combination with airport landing charges.

\section{The limitations and cost of Carbon Capture and Storage}

Generating electricity from renewables for use in heating, industry and transport is straightforward and easy. This is the case, even if a high level of taxation on the extraction of fossil fuels might be needed to make the conversion of carbon dioxide and hydrogen by means of electricity into synthetic fuels competitive with fossil fuels, which now are continuing to poison the atmosphere. The implication would be a significant reduction in their use, whether replaced by the direct use of electricity, in the form of synthetic fuels, or via a reduced use of energy.

Note in this context that the CCS (Carbon Capture and Storage) technology is still struggling with the problem that most fossil fuels contain sulphur, which means that any steel in the storage and transport facilities is prone to be attacked by sulphuric acid. There is no doubt that there is a solution to this difficulty, but it will imply considerable additional cost. The CCS technology has not so far made any serious impact on emissions. To make this point clear, it is useful to mention that as late as 2017, the UK Carbon Capture and Storage Research Centre (UKCCSRC) of the University of Southampton summarized this problem with the caption:

Fraction of C stored must rise from zero to $100 \%$

A further discussion of the practical problems which CCS has to overcome is useful here. The Schwarze Pumpe coalfired power station in eastern Germany was commissioned in 1979 and Wikipedia (2020b) reports it as operational. Planning permission for construction of the facilities for deep underground injection of the carbon dioxide and the $200 \mathrm{~km}$ pipeline to its propose injection site in western Germany had not as yet been granted when Burchhardt $(2010)^{5}$ presented his paper. ZeroCO2.no (undated) reports that for some time the liquified carbon dioxide was transported by truck to Altmark, but that this practice was stopped on account of public protest and lack of clarity concerning its legality. Eventually, storage started in 2011 at Ketzin in the Berlin area (GFZ German Research Centre for Geosciences 2011). This "not in my backyard problem" may also arise in relation to transport and storage of carbon dioxide from biomethane burning power stations, but not on the scale which arises for continuing to burn fossil fuels under CCS.

There are, besides the public perception problem, which has an element of "not in my backyard" also clear indications that CCS is commercially quite costly:

Last April, another flagship Alberta CCS plan bit the dust when TransAlta Corp. cancelled the Pioneer project that was to have captured the carbon from the Keephills 3 coal-fired power plant. Despite government funding, TransAlta and its partners decided they could not justify the expense. (Blackwell 2013)

\footnotetext{
${ }^{5}$ Burchhardt does not disclose how the $\mathrm{CO}_{2}$ was to be transported, nor what kind of geological formation was used. The Swedish state owned energy corporation Vattenfall, which originally pioneered the project, considered a number of storage techniques, which included deep underground, and under oil deposits in the North Sea (Strömberg 2008).
} 
We conclude that $\mathrm{PC}$ power plants with $\mathrm{CO}_{2}$ capture are likely to remain less competitive than natural gas combined cycle (without $\mathrm{CO}_{2}$ capture) and on-shore wind power plants, both from a levelized and marginal COE point of view. (Supekar and Skerlos 2015)

It is also the case that, in practice, CCS is associated with additional costs, in comparison with extraction of fossil fuels.

Apart from pure storage, carbon dioxide that is captured can also be used for Enhanced Hydrocarbon Recovery. This includes Enhanced Oil Recovery (EOR), Enhanced Gas Recovery (EGR) and Enhanced Coalbed Methane Recovery (ECBM). Any oil or gas that is recovered through these methods would otherwise not be extracted and therefore has an economic value, which offsets some of the costs of $\mathrm{CO}_{2}$ sequestration. (Carbon Capture and Storage Association 2020)

The two strings which I put in italic in italic in the above quote relate to the fact that, given the need to have negative net emissions, the last thing we need is to put additional economic value on fossil fuel extraction, while emissions, if not captured, have no financial cost at all.

\section{Conclusion}

Humanity is well on its way towards causing a serious risk of a major climate crisis associated with a catastrophic level of sea-level rise because of unbridled use of fossil fuels. There are, however, technological means of containing this crisis. Making the implementation of these operational under market economy conditions is best served by a high level of taxation on the extraction of fossil fuel feedstocks, in particular crude oil. Doing so will require global cooperation by governments.

\section{References}

American Chemical Society (2020) It's water vapor, not the $\mathrm{CO}_{2}$. https ://www.acs.org/content/acs/en/climatescience/climatesciencen arratives/its-water-vapor-not-the-co2.html

Associated Press (2020) Wire service content April 11, 2020, at 3:01 a.m. Pennsylvania faces new wave of abandoned oil and gas wells. https://www.usnews.com/news/best-states/pennsylvania/artic les/2020-04-11/pennsylvania-faces-new-wave-of-abandoned-oiland-gas-wells. 11 April 2020

BBC News (2019a) Australia: nation endures hottest day on record. https://www.bbc.co.uk/news/world-australia-50817963

BBC News (2019b) Thousands of people have fled to a beach in Victoria, Australia, to escape bushfires racing towards the coast. https ://www.bbc.co.uk/news/world-australia-50952253
Berger A (1980) The Milankovitch astronomical theory of paleoclimates: a modern review. Vistas Astron 24(Part 2):103-122

Blackwell R (2013) Alberta cancels funding for carbon capture project. https://www.theglobeandmail.com/report-on-business/indus try-news/energy-and-resources/alberta-cancels-funding-for-carbo n-capture-project/article9024237/

Blanchon P, Shaw J (1995) Reef drowning during the last deglaciation: evidence for catastrophic sea-level rise and ice-sheet collapse. Geology 23(1):4-5

Bloomberg (2020) Jakarta hit by flooding as cyclones trigger extreme rainfall. https://www.bloomberg.com/news/articles/2020-02-24/ jakarta-hit-by-floods-as-tropical-cyclones-trigger-heavy-rain

Brancato V, Rignot E, Milillo P, Morlighem M, Mouginot J, An L, Scheuchl B, Jeong S, Rizzolli P, Bueso Bello JL, Prats-Iraola P (2020) Grounding line retreat of Denman Glacier, East Antarctica, measured with COSMO-SkyMed radar interferometry data. Geophys Res Lett 47:1-14. https://doi.org/10.1029/2019GL086291

Burchhardt U (2010) Abscheidung und Einlagerung von Kohlendioxid (CCS Technologie) (Capture and storage of carbon dioxide) Paper presented at an expert meeting for the Department of the Environment (Landesamt für Umweltschutz) of the German Land of Sachsen Anhalt, Halle, 7 October 2010. https://sachsen-anhalt.de/ fileadmin/Bibliothek/Politik_und_Verwaltung/MLU/LAU/Klima /Klimaschutz/Dateien/Vortrag_Vattenfall_CCS-Technologien.pdf

Carbon Capture and Storage Association (2020) Enhanced hydrocarbon recovery. http://www.ccsassociation.org/what-is-ccs/storage/ enhancedhydrocarbon-recovery/

Eavis P (2020) The last time the global economy was in free fall, an economic savior showed up in southwestern Pennsylvania. Energy companies, which had discovered a way to get at the state's vast natural-gas reserves, invested billions of dollars in the region, cushioning the blow of the Great Recession. https://www.nytim es.com/2020/03/31/business/energy-environment/pennsylvaniashale-gas-fracking.html

Egyptian Streets (2020) Heavy rainfall brings flooding to Egypt, houses collapse and electrical transistors explode. https://egyptianstreets .com/2020/03/13/heavy-rainfall-brings-flooding-to-egypt-house s-collapse-and-electrical-transistors-explode/

Environmental Defence Fund (EDF) (2018) Report estimates Pennsylvania oil and gas methane emissions nearly five times higher than state's figures. https://www.edf.org/media/edf-analysis-finds -pennsylvania-oil-and-gas-methane-emissions-are-double-previ ous-estimate

Environmental Defence Fund (EDF) (2020) EDF analysis finds pennsylvania oil and gas methane emissions are double previous estimate. https://www.edf.org/media/edf-analysis-finds-pennsylvan ia-oil-and-gas-methane-emissions-are-double-previous-estimate

Environmental Protection Agency (2018) ECMPS reporting instructions emissions. https://www.epa.gov/sites/production/files/201806/documents/ecmps_emissions_reporting_instructions.pdf

Fagan L (2020) Leaving Jakarta: what happens if Indonesia https:// www.sustainability-times.com/environmental-protection/leavingjakarta-what-happens-if-indonesia-moves-a-capital/

Fernández YB, Soares A, Villa R, Vale P, Cartmell E (2014) Carbon capture and biogas enhancement by carbon dioxide enrichment of anaerobic digesters treating sewage sludge or food waste. Bioresour Technol 159:1-7

GFZ German Research Centre for Geosciences (2011) $\mathrm{CO}_{2}$ from Schwarze Pumpe in a trial experiment at the pilot site Ketzin. https://www.gfz-potsdam.de/en/media-and-communication/news/ details/article/co2-from-schwarze-pumpe-in-a-trial-experiment -at-the-pilot-site-ketzin/

Graver B, Zhang K, Rutherford D (2018) $\mathrm{CO}_{2}$ emissions from commercial aviation. ICCT (International Council on Clean Transportation), 2019. https://theicct.org/sites/default/files/publicatio ns/ICCT_CO2-commercl-aviation-2018_20190918.pdf 
Hansen J, Sato M, Hearty P, Ruedy R, Kelley M, Masson-Delmotte V, Russell G, Tselioudis G, Cao J, Rignot E, Velicogna I, Tormey B, Donovan B, Kandiano E, von Schuckmann K, Kharecha P, Legrande AN, Bauer M, Lo K-W (2016) Ice melt, sea level rise and superstorms: evidence from paleoclimate data, climate modeling, and modern observations that $2^{\circ} \mathrm{C}$ global warming could be dangerous. Atmospheric Chem Phys 16:3761-3812. https://doi.org/10.5194/acp-16-3761-2016

Heesterman ARG (2018) Synthetic carbohydrate compounds and their integration with renewable electricity supplies: it is a sustainable approach towards containing catastrophic climate change. Clean Technol Environ Policy 20(4):771-783

Heesterman ARG (2019) Renewable energy supply and carbon capture: capturing all the carbon dioxide at zero cost. Clean Technol Environ Policy 21(6):1177-1191

Heesterman ARG, Heesterman WH (2013) Rediscovering sustainability: economics of the finite earth gower. Taylor and Francis. ISBN 9781409444565

Heesterman WH (2020) Anaerobic digestion: power from waste. Responsible Science 2020(2):21

Henley J (2020) Wine cooler: global heating helps Sweden's vineyards to success. https://www.theguardian.com/world/2020/ mar/20/wine-cooler-global-heating-helps-swedens-vineyardsto-success

Hooijer A, Silvious M, Wösten H, Page S (2006) PEAT-CO2: assessment of $\mathrm{CO}_{2}$ emissions from drained peatlands in SE Asia. https://www.researchgate.net/publication/285726396_PEATCO2_assessment_of_CO2_emissions_from_drained_peatl ands_in_SE_Asia

Jouzel J, Dreyfus GB, Masson-Delmotte V, Hoffmann G (2007) Orbital and millennial antarctic climate variability over the past 800,000 years. Science 317:793. https://doi.org/10.1126/ science.1141038researchgate.net/publication/6223217_Orbit al_and_Millennial_Antarctic_Climate_Variability_over_the_ Past_800000_Years

Kimani A (2020) 2020: the year of the oil bankruptcies oilprice. https://oilprice.com/Energy/Energy-General/2020-The-Year-OfThe-Oil-Bankruptcies.html

Konschnik K, Jordaan SM (2018) Reducing fugitive methane emissions from the North American oil and gas sector: a proposed science policy framework. Clim Policy 18(9):2-19

Lenton TM, Rockström J, Gaffney O, Rahmstorf S, Richardson K, Steffen W, Schellnhuber HJ (2019) Climate tipping points-too risky to bet against. Nature 575:592-595

McClintock J (2012) Lost Antarctica: adventures in a disappearing land. Palgrave MacMillan, New York. ISBN 978-0-11245-2

Menon S (2020) Mission: methane, vol 51, no 2, Spring 2020. EDF Solutions, pp 9-11

Milankovitch M (1930) Mathematische Klimalehre und Astronomische Theorie der Klimaschwankungen (The mathematics of climate change and its relation to astronomy). In Handbuch der Klimalogie, herausgegeben von W. Köppen und R. Geiger, Bd. 1. Allgemeine Klimatologie TA (eds) Borntrager, Berlin (Kraus reprint, Nenderlen, Lichtenstein. 1972) Band 1 Teil A

Milman O (2020) The Guardian, 20 March 2020. Greenland Ice melt seas uo by $2 \mathrm{~mm}$ in two months, p 31. https://www.theguardia n.com/science/2020/mar/19/greenland-ice-melt-sea-level-riseclimate-crisis

Needham HD (1962) Ice-rafted rocks from the Atlantic Ocean off the coast of the Cape of good hope. Deep Sea Research and Oceanographic Abstracts 9(11-12):475-486

New Scientist (2008) When crocodiles roamed the Arctic. https:// www.newscientist.com/article/mg19826611-200-when-croco diles-roamed-the-arctic/
Pigou AC (1932) The economics of welfare (4th ed, 1 st 1920). Macmillan, London. https://oll.libertyfund.org/simple.php?id=1410

Project Cargo Journal (2019) EC wants to end tax exemptions for maritime and aviation fuels. https://www.projectcargojournal. com/shipping/2019/12/12/ec-wants-to-end-tax-exemptions-onmaritime-and-aviation-fuels/?gdpr=accept

Rao J (2011) On fourth of July, earth is farthest from the sun. Space. https://www.space.com/12161-fourth-july-earth-sun-distanceaphelion.html

Rosen E (2017) As billions more fly, here's how aviation could evolve. National Geographic, June 20, 2017. https://www.natio nalgeographic.com/environment/urban-expeditions/transporta tion/air-travel-fuel-emissions-environment/

Royal Netherlands Institute for Sea Research (2019) Present $\mathrm{CO}_{2}$ levels caused 20-metre-sea-level rise in the past. https://www. nioz.nl/en/news/present-co2-levels-caused-20-metre-sea-level -rise-in-the-past

Ryckebosch E, Drouillon M, Vervaeren H (2011) Techniques for transformation of biogas to biomethane. Biomass Bioenergy 35(5):1633-1645

Steely A (2020) Taxing aviation fuel. House of Commons Library (UK). https://commonslibrary.parliament.uk/research-briefings/ sn00523/

Steffen W, Rockström J, Richardson K, Lenton TM, Folk C, Liverman D, Summerhayes CP, Barnosky AD, Cornella SE, Crucifix M, Donges JF, Fetzer I, Lade SJ, Scheffer M, Ricarda WR, Schellnhuber HJ (2018) Trajectories of the earth system in the anthropocene. Proc Natl Acad Sci Am: PNAS 115(33):8252-8259

Strömberg L (2008) Carbon Capture and Storage-Technology, costs and way forward. https:/group.vattenfall.com/contentassets/ da563d31cf814e8a901c3e6dd66c88b3/corporate/investors/x investors/2.-investor-presentations/lars-strombergccs-and-renew a.pdf

Stukman D (2019) Climate change: rain melting greenland ice sheet' even in winter. https://www.bbc.co.uk/news/science-environmen $\mathrm{t}-47485847$

Sugarcane (2020) Ethanol. https://sugarcane.org/ethanol/

Supekar SD, Skerlos SJ (2015) Reassessing the efficiency penalty from carbon capture in coal-fired power plants. Environ Sci Technol 49(20):12576-12584

The Engineering Toolbox (undated) "Solubility of gases in water". https://www.engineeringtoolbox.com/gases-solubility-water -d_1148.html

UKCCSRC (UK Carbon Capture and Storage Research Centre) (2019). https://cdn.southampton.ac.uk/assets/imported/trans forms/content-block/UsefulDownloads_Download/C17A8 84C5B174765880A0A5F53756BC6/jon\%20gibbins.pdf

United Nations (2019) Peace dignity and equality on a healthy planet. https://www.un.org/en/sections/issues-depth/climate-change/

Vaughan A (2020) Leaked report says UK net zero climate goal may increase air pollution. New Scientist. 6 Mar 2020 https://www. newscientist.com/article/2236385-leaked-report-says-uk-netzero-climate-goal-may-increase-air-pollution/

Wadhams P (2016) A farewell to ice. A report from the Arctic. Penguin Random House, UK, 2016 ISBN 978-0-241-00941-3

Watts J (2019) We have 12 years to limit climate change catastrophe, warns UN" The Guardian. 8 Oct 2019. https://www.theguardia n.com/environment/2018/oct/08/global-warming-must-notexceed-15c-warns-landmark-un-report

Wikipedia (2020a) Climate of Egypt. https://en.wikipedia.org/wiki/ Climate_of_Egypt\#Rainfall

Wikipedia (2020b) Swartze Pumpe power station. https://en.wikip edia.org/wiki/Schwarze_Pumpe_power_station 
WorldAtlas (2017) How far is the earth away from the Sun? https ://www.worldatlas.com/articles/how-far-is-the-earth-from-thesun.html

Yale School of Forestry \& Environmental Studies (Global Forest Atlas) 2020: Sugar cane, palm oil, and biofuels in the Amazon. https://globalforestatlas.yale.edu/amazon/land-use-and-agric ulture/biofuels

ZeroCO2.no (undated, update of website stopped in 2016) "Schwarze Pumpe" http://www.zeroco2.no/projects/vattenfall2019s-oxyfu el-pilot-plant-201c-schwarze-pumpe201d
Publisher's Note Springer Nature remains neutral with regard to jurisdictional claims in published maps and institutional affiliations. 